\title{
KEPEMIMPINAN KEPALA SEKOLAH DAN PENGARUHNYA TERHADAP PENINGKATAN PEDAGOGIK GURU PENDIDIKAN AGAMA ISLAM DI SMP NEGERI 3 KARAWANG JAWA BARAT
}

\author{
M. Hidayat Ginanjar, Marfuah As-Surur \\ STAI Al-Hidayah Bogor \\ m.hidayatginanjar@gmail.com
}

Received: 19-07-2018, Accepted: 25-07-2018, Published:30-07-2018

\begin{abstract}
Abstrak
Penelitian ini bertujuan untuk menganalisis kepemimpinan kepala sekolah terhadap peningkatan kompetensi pedagogik guru pendidikan agama Islam (PAI). Kompetensi pedagogik adalah salah satu dari empat kompetensi yang harus dimiliki oleh guru untuk dapat memahami indikatorindikator dalam mengukur keberhasilan melaksanakan tugasnya secara pedagogik yang mencakup pemahaman landasan kependidikan, pemahaman terhadap peserta didik, pengembangan kurikulum, rancangan pembelajaran, pemanfaatan teknologi pembelajaran, evaluasi hasil belajar, dan pemahaman terhadap pengembangan peserta didik untuk mengaktualisasikan berbagai potensi yang dimilikinya. Penelitian ini dilakukan di SMP Negeri 3 Kabupaten Karawang Jawa Barat. Penelitian ini merupakan penelitian kuantitatif dengan menggunakan metode survey teknik korelasional. Teknik pengumpulan data menggunakan angket, wawancara, observasi dan studi dokumentasi. Sedangkan analisis data untuk menjawab hipotesis penelitian menggunakan statistik model analisis jalur (path analysis). Adapun populasi dalam penelitian ini adalah guru mata pelajaran PAl. Berdasarkan hasil pengolahan data, diperoleh $r$ hitung sebesar 0,183 dalam indeks korelasi $r$ product moment berkisar antara $0,00-0,20$, artinya terdapat pengaruh antara kepemimpinan kepala sekolah terhadap peningkatan kompetensi pedagogik guru PAI. Hasil perhitungan dan analisis tersebut menunjukan bahwa kepemimpinan kepala sekolah berpengaruh positif terhadap kompetensi pedagogik guru mata pelajaran PAI untuk mewujudkan efektivitas pembelajaran.
\end{abstract}

\begin{abstract}
This study aims to analyze the leadership of the school principal to increase pedagogic competence of Islamic education teachers (PAI). Pedagogic competence is one of the four competencies teachers must have to be able to understand the indicators in measuring the success of carrying out their tasks pedagogically covering understanding of educational base, understanding of learners, curriculum development, learning design, utilization of learning technology, evaluation of learning outcomes, and an understanding of the development of learners to actualize their potentials. This research was conducted in SMP Negeri 3 Kabupaten Karawang West Java. This research is a quantitative research using correlational technique survey method. Data collection techniques used questionnaires, interviews, observations and documentation studies. While the data analysis to answer the research hypothesis using path analysis model analysis (path analysis). The population in this study is the teacher of PAI subjects. Based on the results of data processing, obtained $r$ calculation of 0.183 in the correlation index $r$ product moment ranged from 0.00 to 0.20 , meaning there is an influence between the leadership of the school principal to increase pedagogic competence of teachers PAI. The results of these calculations and analysis shows that the leadership of the principal has a positive effect on the pedagogical competence of the PAl subject teachers to realize the effectiveness of learning.
\end{abstract}

Keywords: principal's leadership, pedagogic competence, PAl teacher. 


\section{A. Pendahuluan}

Dalam pembukaan Undang Undang Dasar Negara Republik Indonesia Tahun 1945 dinyatakan bahwa tujuan pendidikan Nasional adalah untuk melindungi segenap bangsa dan seluruh tumpah darah Indonesia dan untuk memajukan kesejahteraan umum, mencerdaskan kehidupan bangsa, dan ikut melaksanakan ketertiban dunia berdasarkan kemerdekaan, perdamaian abadi dan keadilan sosial. Untuk mewujudkan tujuan tersebut, pendidikan merupakan faktor yang sangat menentukan (Undang-Undang RI No.14 Tahun 2005). Selain itu, pendidikan dapat mendorong terciptanya beragam perkembangan dari ragam pembawaan manusia, baik dari aspek jasmani, psikologi, intelektual, spiritual, dan keterampilan (Zamakhsyari Dhofier: 213-229).

Sementara itu, pendidikan difahami sebagai modal sosial, modal politik, modal ekonomi, dan modal kebudayaan (Djiwandono, 2004:105).

Pendidikan juga merupakan sistem yang mencakup beberapa aspek, antara lain; Pertama, yaitu usaha sadar yang terncana untuk mewujudkan suasana belajar dan proses pembelajaran. Pendidikan harus disiapkan dengan matang mulai dari mutu guru, kelas, media, metode, evaluasi, hingga prasarana pendukung keberhasilan pendidikan. Kedua, potensi siswa berupa sikap, pengetahuan dan keterampilan. Tujuan pendidikan melahirkan manusia yang pintar, terampil dan saleh. Ketiga, ilmu yang bermanfaat bagi individu, masyarakat, dan bangsa (Jejen Musfah, 2015: 9-11).

Dari ketiga aspek tersebut dapat dijelaskan bahwa pendidikan adalah usaha sadar untuk mengembangkan akhlak, keterampilan, dan pengetahuan anak di sekolah maupun di rumah, agar hidup mereka bahagia dan bermanfaat bagi masyarakat dan bangsa. Untuk itu, Mulyasa mengatakan bahwa guru sebagai main person harus ditingkatkan kompetensinya untuk mendapatkan guru yang baik dan profesional, yang memiliki kompetensi untuk melaksanakan fungsi dan tujuan sekolah khususnya, serta tujuan pendidikan pada umumnya, sesuai kebutuhan masyarakat dan tuntutan zaman (E.Mulyasa: 2007: 78).

Guru merupakan seorang manajer dalam pembelajaran, yang bertanggung jawab terhadap perencanaan, pelaksanaan, dan 
penilaian perubahan atau perbaikan program pembelajaran (E.Mulyasa, 2007: 78). Pada hakikatnya guru adalah seorang pendidik. Mendidik adalah sebuah profesi yang harus dipersiapkan terlebih dahulu dengan persiapan khusus. Karena, pendidikan berhubungan dengan manusia, yang menjadi poros dan penggerak utama kehidupan ini. Guru menjadi sumber utama informasi serta ilmu pengetahuan bagi anak didiknya. Dia perlu memberikan arahan dan petunjuk kepada murid-muridnya, sehingga dia mampu menyiapkan generasi yang berilmu dan warga negara yang berakhlak mulia. Semua ini dapat diwujudkan melalui beberapa peran yang dapat dilakukan oleh sang guru salah satunya di dalam kelas (Mahmud Khalifah, 2012: 13).

\section{Dalam}

Undang-Undang

Republik Indonesia No.14 Tahun 2005 tentang Guru dan Dosen, pasal 10 ayat (1) dinyatakan bahwa guru harus memiliki empat kompetensi yaitu; kompetensi kepribadian, kompetensi sosial, kompetensi pedagogik, dan kompetensi profesional.

Secara Pedagogis, kompetensi guru dalam mengelola pembelajaran perlu mendapat perhatian yang serius. Hal ini penting, karena pendidikan di Indonesia dinyatakan kurang berhasil oleh sebagian masyarakat, dinilai kering dari aspek psikologis, dan sekolah nampak lebih mekanis sehingga peserta didik cenderung kerdil karena tidak mempunyai dunianya sendiri. Peserta didik dipandang sebagai bejana yang akan diisi air (ilmu) oleh gurunya. Oleh karena itu, pembelajaran nampak seperti sebuah kegiatan menabung, peserta didik sebagai "celengan" dan guru sebagai "penabung" (E.Mulyasa, 2007: 78). Padahal, setiap manusia dilahirkan dengan dibekali potensi masing-masing yang berbeda dan sebenarnya tugas guru hanya mengarahkan dan mengembangkan potensi yang dimiliki oleh siswasiswanya.

Guru yang baik tetap berproses untuk meningkatkan kualitas ilmu, strategi pembelajaran, maupun kepribadiannya. Guru yang merasa sudah baik berarti ia bukan guru yang baik karena hal tersebut merupakan pertanda bahwa ia enggan berproses menjadi lebih baik. Guru yang ideal adalah guru yang pada saat bersamaan siap menjadi peserta didik yang baik, yang senantiasa menuntut ilmu dan keterampilan sundul langit. Ini merupakan sikap mandiri dalam belajar, yang berarti tetap belajar 
meski telah menjadi pengajar (Ahmad Tafsir, 2011: 105).

Prinsip profesionalitas yang tercantum pada pasal 8 UU Guru dan Dosen, Guru wajib memiliki kualifikasi akademik, kompetensi, sertifikat pendidik, sehat jasmani dan rohani, serta memiliki kemampuan untuk mewujudkan tujuan pendidikan Nasional. Disini kompetensi guru sebagaimana yang dimaksud dalam pasal 8 meliputi Kompetensi pedagogik, kompetensi kepribadian, kompetensi sosial dan kompetensi profesional (Undang-Undang Guru Dan Dosen UU RI No. 14 Th. 2005).

M. Dalyono menegaskan bahwa faktor penting yang menyebabkan munculnya kesulitan belajar pada siswa adalah faktor lingkungan sekolah, salah satunya dari lemahnya kompetensi pedagogik guru tersebut, seperti guru yang tidak berkualitas dan mengajar bukan pada faktanya, hubungan guru dengan murid yang kurang baik, guru yang menuntut standar pelajaran di atas kemampuan anak, guru tidak memiliki kecakapan dalam usaha diagnosis kesulitan belajar, dan guru menggunakan metode mengajar yang tidak tepat dan dapat menimbulkan kesulitan besar (M. Dalyono, 2009: 242).
Peraturan Pemerintah Nomor 74 Tahun 2008 pasal 3 ayat (4) bahwa kompetensi pedagogik merupakan kemampuan guru dalam pengelolaan pembelajaran peserta didik yang sekurang-kurangnya meliputi; 1) Pemahaman wawasan atau landasan kependidikan, 2) Pemahaman terhadap peserta didik, 3) Pengembangan kurikulum atau silabus, 4) Perancangan pembelajaran, 5) Pelaksanaan pembelajaran yang mendidik dan dialogis, 6) Pemanfaatan teknologi pembelajaran, 7) Evaluasi hasil belajar, 8) Pengembangan peserta didik untuk mengaktualisasikan berbagai potensi yang dimilikinya (Peraturan Pemerintah Nomor 74 Tahun 2008).

Meskipun demikian, akhir-akhir ini yang dikembangkan adalah corak pendidikan yang berorientasi pada kompetensi anak didik (Student Center) tetapi juga tidak mengurangi pentingnya seorang guru dalam proses pembelajaran. Karena keberhasilan proses belajar mengajar tersebut tidak terlepas dari guru sebagai tenaga pengajar, sebab guru menjadi first person di kelas yang mempunyai tanggung jawab yang besar terhadap keberhasilan 
mengajar. Sehingga guru perlu profesionalisme dalam mengajar.

Begitupun dengan tenaga kependidikan (kepala sekolah, pengawas, tenaga perpustakaan, tenaga administrasi) mereka bertugas melaksanakan administrasi, pengembangan, pengawasan, dan pelayanan teknis, untuk menunjang proses pendidikan pada satuan pendidikan. Sehubungan dengan tuntutan ke arah profesionalisme tenaga pendidikdan kependidikan Islam, maka semakin dirasakannya desakkan untuk peningkatan mutu pendidikan Islam pada setiap jenis dan jenjang pendidikan Islam yang telah menjadi komitmen pendidikan nasional (Sulistiyorini, 2009: 66).

Meningkatkan kompetensi pedagogik guru tidak dapat terlepas dari peran kepala sekolah sebagai penentu kebijakan, dan yang memberikan pengarahan dan bimbingan serta memotivasi para guru PAI. Karena kepala sekolah harus mampu membantu memberi arahan guru-guru dalam meningkatkan kapasitasnya untuk membelajarkan peserta didik secara optimal. Dengan demikian, maka kepala sekolah diharapkan dengan sendirinya dapat mengelola lembaga pendidikan ke arah perkembangan yang lebih baik dan menjanjikan masa depan (Sulistiyorini, 2009: 66).

Maka dari itu, peran terbesar dalam peningkatan mutu pendidikan adalah dari kualitas kepemimpinan. Kepemimpinan pendidikan merupakan proses mempengaruhi dan membimbing seorang pemimpin kepada pendidik dan tenaga kependidikan untuk melaksanakan tugas-tugas kependidikan dan penelitian dengan menggunakan fasilitas pendidikan yang ada, baik secara individu maupun kelompok, agar tujuan pendidikan tercapai secara efektif dan efisien (Jejen Musfah, 2015: 9-11).

Kepemimpinan berkaitan dengan masalah kepala sekolah dalam meningkatkan kompetensi guru. Perilaku kepala sekolah harus dapat meningkatkan kompetensi para guru dengan memberi motivasi, menunjukkan rasa bersahabat, dekat dan penuh pertimbangan terhadap para guru. Kepala sekolah sebagai penanggungjawab pendidikan dan pembelajaran di sekolah hendaknya dapat meyakinkan kepada masyarakat bahwa segala sesuatu telah berjalan dengan baik yang termasuk di dalamnya, salah satunya adalah pemanfaatan dan penyediaan sumber daya guru. Bagaimanapun kepala 
sekolah merupakan unsur vital bagi efektivitas lembaga pendidikan. Kepala sekolah yang baik akan bersifat dinamis menyiapkan berbagai macam program pendidikan (Sulistiyorini, 2009: 129). Hal ini sejalan dengan firman Allah dalam al-Qur'an surat Al-Anbiya ayat 73 dan surat Al-Sajdah ayat 24.

Keahlian manajerial dan kepemimpinan merupakan dua peran yang berbeda. Seorang manajer yang baik yaitu seseorang yang mampu menangani kompleksitas organisasi, dia adalah ahli perencanaan strategik dan operasional yang jujur, mampu mengorganisasikan aktivitas organisasi secara terkoordinasi, dan mampu mengevaluasi secara realiable dan valid. Adapun seorang pemimpin yang efektif mampu membangun motivasi staf, menentukan arah, menangani perubahan secara benar, dan menjadi katalisator yang mampu mewarnai sikap dan perilaku staf (Jejen Musfah, 2015: 303).

Dua peran kepala sekolah sebagai manajer dan pemimpin dalam organisasi semestinya seperti dua mata uang yang tidak dapat dipisahkan karena tanpa keahlian manajerial, seorang pemimpin akan kesulitan menetapkan langkahlangkah kerja rasional yang didasari oleh nilai-nilai teoritis pengembangan organisasi. Kondisi itu dapat menimbulkan kemandekkan. Sebaliknya, apabila seorang manajer tidak memiliki keahlian memimpin, maka lambat laun organisasi akan kehilangan pamornya karena tidak ada orang yang dijadikan rujukan, memberi motivasi dan menentukan arah organisasi (Jejen Musfah, 2015: 303).

Berdasarkan uraian-uraian di atas, penulis menyimpulkan seiring semakin meningkatnya perkembangan IImu Pengetahuan dan Teknologi (IPTEK) sehingga timbul tuntutan untuk lebih meningkatan lagi kualitas Sumber Daya Manusia (SDM), dan hal ini juga tidak dapat terlepas dari peran penting Pendidikan Agama Islam, dimana pendidikan akan berperan sebagai Way of Life sehingga dapat menjadi tameng dari pengaruh buruk perkembangan zaman yang semakin maju.

Bagi peserta didik yang masih menginjak usia remaja dimana sering terbawa arus negatif, jika pendidikan agama yang diajarkannya tidak begitu kuat dan benar-benar tertanam dalam jiwa mereka. Akan tetapi pelajaran PAI ini hanya diajarkan selama dua jam pelajaran dalam sepekan atau hanya ada sekali tatap muka dalam satu pekan. Sehingga untuk mencapai 
tujuan pembelajaran PAl bukan hal yang mudah bagi Guru PAl itu sendiri.

Latar belakang penulis melakukan penelitian di SMPN 3 Karawang adalah untuk mengetahui lebih dalam seberapa kuat pengaruh kepemimpinan kepala sekolah terhadap kompetensi pedagogik guru PAl yang mengajar pada 36 rombel, dengan jumlah rata-rata 12 rombel di setiap tingkatan kelas.

Berdasarkan hasil observasi, bahwa SMPN 3 Karawang memiliki beberapa kegiatan ekstra kulikuler keagamaan yang terbilang cukup aktif dan memiliki jumlah peserta yang banyak. Dengan jumlah guru PAI yang terbatas bila dibanding dengan jumlah rombel yang banyak, namun para guru PAI mampu membangkitkan semangat peserta didik dalam mengembangkan potensinya di bidang keagamaan.

Penulis ingin mengetahui lebih mendalam tentang kinerja para guru PAl tersebut dalam mengelola 36 kelas, dan bagaimana kualitas kepemimpinan kepala sekolah dalam membina para guru PAl tersebut agar lebih efektif dan maksimal dalam mengelola kelas, yang nantinya akan berdampak pada kualitas seluruh peserta didik, baik itu pada pembinaan akhlak, kompetensi, kreativitas dan lain sebagainya.
Permasalahan yang ingin diungkap penulis yaitu untuk mengetahui efektifitas kepemimpinan yang dijalankan kepala sekolah seiring dengan kemajuan ilmu pengetahuan dan teknologi, sehingga meskipun jumlah guru PAI yang tidak memadai, dan waktu kepala sekolah yang terbatas namun selalu memantau perkembangan kemampuan mengelola pembelajaran para guru Pendidikan Agama Islam.

Berdasarkan permasalahan tersebut, penulis tertarik melakukan penelitian mendalam untuk mengetahui pengaruh kepemimpinan kepala sekolah terhadap peningkatan kompetensi pedagogik para guru PAI agar terciptanya kegiatan pembelajaran yang efektif dan efisien guna meningkatkan mutu pendidikan Islam dengan mengamati secara teliti dan sistematis melalui penelitian akademik mengenai Pengaruh Kepemimpinan Kepala Sekolah Terhadap Peningkatan Kompetensi Pedagogik Guru Pendidikan Agama Islam (PAI) Di Sekolah Menengah Pertama Negeri (SMPN) 3 Karawang Tahun Ajaran 2016/2017.

\section{B. Tinjauan Teoritis}

\section{Kepemimpinan}

Kepala Sekolah 
Kepemimpinan berasal dari kata "pemimpin", artinya adalah orang yang memimpin

(https://kbbi.web.id, diposting 15 April 2017). Menurut Kartini Kartono (1994: 33), pemimpin adalah seorang pribadi yang memiliki kecakapan dan kelebihan khususnya kecakapan dan kelebihan disatu bidang, sehingga dia mampu mempengaruhi orang-orang lain untuk bersama-sama melakukan aktivitasaktivitas tertentu, demi pencapaian satu atau beberapa tujuan (1994: 33). Pemimpin seharusnya adalah figur yang memiliki karakteristik pemimpin yang ideal seperti memiliki visi dan komitmen pada visinya, kompetensi, integritas, kejujuran, kesediaan mendengar, dan menerima kritik serta masukan, tidak diktator dalam membuat dan menetapkan suatu kebijakan-kebijakannya (M.Hidayat Ginanjar, 2017: 2-3). Sementara itu, Miftah Thoha dalam bukunya Perilaku Organisasi (1983: 255) menjelaskan bahwa pemimpin adalah seseorang yang memiliki kemampuan memimpin, artinya memiliki kemampuan untuk mempengaruhi orang lain atau kelompok tanpa mengindahkan bentuk alasannya. Menurut Henry Pratt Faiechild yang dikutip Kartini Kartono (1994: 33), bahwa pemimpin ialah seseorang yang dengan jalan memprakarsai tingkah laku sosial dengan mengatur, mengarahkan, mengorganisir atau mengontrol usaha/upaya orang lain atau melalui prestise, kekuasaan dan posisi.

Berdasarkan beberapa pendapat di atas, dapat difahami bahwa pemimpin ialah seorang yang membimbing, memimpin dengan bantuan kualitas-kualitas persuasifnya dan ekseptansi/penerimaan secara sukarela oleh para pengikutnya. Menurut Winardi (2000: 56), seorang pemimpin harus dapat mempengaruhi kelompoknya, jelas karena apabila ia tidak mampu melakukannya maka berarti ia tidak dapat menjalankan tugasnya sebagai pemimpin dengan baik (Winardi, 2000: 56). Sedangkan menurut Wahjosoemidjo (2005: 104), pemimpin tidak berdiri di samping, melainkan mereka memberikan dorongan dan memacu (to prod), berdiri di depan yang memberikan kemudahan untuk kemajuan serta memberikan inspirasi organisasi dalam mencapai tujuan. Fungsi seorang pemimpin menurut Wnardi adalah "memimpin" dan bukanlah "memaksa", ia "menarik pengikutnya hingga mencapai puncak prestasi yang menuntut anggapan mereka semula tidak mungkin dicapai. Seorang pemimpin harus mengenal sifat-sifat 
indipividual pengiku-pengikutnya dan ia mengetahui kualitas-kualitas apa akan merangsang meraka untuk bekerja sebaik mungkin. Seorang pemimpin saat yang bersangkutan mengabdi dan memimpin ia memiliki kemampuan untuk membangkitkan kekuatankekuatan emosional maupun rasional para pengikutnya. la dapat merangsang pihak lain (Winardi, 2000:57).

Berdasarkan pemahaman tentang arti pemimpin, maka hal itu tidak dapat dipisahkan dengan fungsi dan perannya dalam praktik kepemimpinan. Kepemimpinan yang dimaksud merupakan sesuatu yang mengandung makna atau nilai-nilai yang dapat dikembangkan. Para peneliti biasanya mendefinisikan "kepemimpinan" menurut pandangan pribadi mereka, serta aspek-aspek fenomena dari kepentingan yang paling baik bagi para pakar yang bersangkutan. Pendekatan (approach) situasi untuk menerangkan kepemimpinan menyatakan bahwa harus terdapat cukup banyak fleksibilitas dalam memahami arti kepemimpinan. Bahkan Gary A.Yukl (1981:2-5) membuat suatu kesimpulan, bahwa: There are almost as many definitions of leadership as there are persons who have attempted to define the concept (Gary A.Yukl, 1981: 2-5).
Menurut Ismail Nawawi Uha (2014: 158), kepemimpinan bersifat multi dimensi. Pada teori ini, dianggap bahwa kepemimpinan terdiri atas tiga elemen, yakni; pemimpin, pengikut, dan situasi. Situasi dianggap sebagai elemen yang terpenting karena ia memiliki paling banyak variabel. Sedangkan menurut Wahjosumidjo (2013:17), kepemimpinan diterjemahkan ke dalam sifat-sifat, perilaku pribadi, pengaruh terhadap orang lain, pola-pola interaksi, hubungan kerjasama antarperan, kedudukan dari suatu jabatan administratif, dan persepsi dari lain-lain tentang legitimasi pengaruh. Sedangkan menurut Winardi (2000: 58), kepemimpinan adalah suatu pertumbuhan alami dari orang-orang yang berserikat untuk suatu tujuan dalam suatu kelompok. Menurut Uha (2014:160), kepemimpinan adalah bagian dari manajemen, tetapi tidak semuanya, misalnya para manajer perlu membuat rencana dan mengorganisir, tetapi yang diminta pemimpin hanyalah agar mereka mempengaruhi orang lain untuk ikut.

Selanjutnya, Koontz memberikan definisi kepemimpinan yaitu, "The function of leadership, therefore, is to induce or persuade all subordinates of followers to contribute williangly to 
organizational goals in accordance with their maximum capability" (Koonttz, et. 1980: 662).

Pendapat ini dapat difahami bahwa fungsi kepemimpinan adalah menginduksi atau membujuk semua bawahan pengikut untuk berkontribusi secara sukarela ke tujuan organisasi sesuai dengan kemampuan maksimum mereka. Berdasarkan pendapat ini, agar para bawahan dengan penuh kemauan serta sesuai dengan kemampuan secara maksimal berhasil mencapai tujuan organisasi, pemimpin harus mampu membujuk (to induce) dan meyakinkan (persuade) bawahan.

Urgensi kepemimpinan secara ringkas ada dalam perkataan al-Afwah al-Audi, penyair jahili yang mengatakan, kekacauan tidak akan menyelamatkan manusia selama tidak ada pemimpin, pemimpin tidak akan ada apabila orang-orang bodoh berkuasa. Rumah tidak akan berdiri kecuali ada di atas tiang, tiang tidak akan ada apabila tidak dibangun fondasi. Apabila fondasi, tiang, dan penghuni berkumpul, maka mereka akan sampai pada tujuan yang dikehendaki (Thariq M. As-Swaidan, Faishal Umar Basyarahil, 2005: 13).

Terkait dengan kepemimpinan kepala sekolah, kepala sekolah sebagai seorang pemimpin harus mampu mendorong timbulnya kemauan yang kuat dengan penuh semangat dan percaya diri dalam memotivasi para guru, staf dan siswa dalam melaksanakan tugas masing-masing serta harus mampu memberikan bimbingan dan arahan para guru, staf dan para siswa serta memberikan dorongan memacu dan berdiri di depan demi kemajuan dan memberikan inspirasi sekolah dalam mencapai tujuan. Hal ini berarti, apabila seorang kepala sekolah ingin berhasil menggerakkan para guru, staf dan para siswa berperilaku dalam mencapai tujuan sekolah. Oleh karena itu, menurut Wahjosumidjo (2013: 105106), kepala sekolah diharuskan untuk; 1) menghindarkan diri dari sikap dan perbuatan yang bersifat memaksa atau bertindak keras terhadap para guru, staf dan para siswa, 2) sebaliknya kepala sekolah harus mampu melakukan perbuatan yang melahirkan kemauan untuk bekerja dengan penuh semangat dan percaya diri terhadap para guru, staf, dan siswa dengan cara: (1) meyakinkan (persuade), berusaha agar para guru, staf dan siswa percaya bahwa apa yang dilakukan adalah benar; (2) membujuk (induce), berusaha meyakinkan para guru, staf dan siswa bahwa apa yang dikerjakan adalah benar. 
Kepala sekolah dalam menjalankan tugasnya di sekolah sebagai pimpinan mempunyai fungsi antara lain: a) Perumus tujuan kerja dan pembuat kebijaksanaan sekolah, b) Pengatur tata kerja sekolah, yang mencakup; 1) Pengatur pembagian tugas dan wewenang, 2) Mengatur petugas pelaksanaan, Menyelenggarakan kegiatan. Supervisi kegiatan sekolah, meliputi; 1) mengawasi kelancaran kegiatan, 2) mengarahkan pelaksanaan kegiatan, 3) mengevaluasi (menilai) pelaksanaan kegiatan, dan 4) membimbing dan meningkatkan kemampuan pelaksanaan dan sebagainya. Apabila kepala sekolah ingin berhasil menggerakkan para guru, staf dan siswa, menurut Wahjosumidjo (2002: 105), kepala sekolah harus: 1) Menghindarkan diri dari sikap dan perbuatan yang bersikap memaksa atau bertindak keras terhadap para guru, staf dan para siswa, 2) Sebaliknya kepala sekolah harus mampu melekukan perbuatan yang melahirkan kemauan untuk bekerja dengan penuh semangat dan percaya diri terhadap para guru, staf dan siswa, dengan cara; (1) meyakinkan (persuade), berusaha agar para gurau, staf dan para siswa percaya apa yang dilakukan adalah benar, (2) membujuk
( induce), berusaha meyakinkan para guru, staf dan siswa bahwa apa yang dikerjakan adalah benar.

Sementara itu, Ngalim Purwanto (2004: 65), mengemukakan 10 peranan yang harus dilakukan oleh kepala sekolah, antara lain: 1) sebagai pelaksana, 2) perencana, 3) seorang ahli, 4) mengawasi hubungan antara anggota-anggota, 5) mewakili kelompok, 6) bertindak sebagai pemberi ganjaran, 7) bertindak sebagai wasit, 8) pemegang tanggung jawab, 9) sebagai seorang pencipta, dan 10) sebagai seorang ayah.

\section{Kompetensi Pedagogik Guru}

Menurut Kamus Besar Bahasa Indonesia (KBBI, Departemen Pendidikan Nasional, 2012: 719), kompetensi diartikan sebagai kewenangan (kekuasaan) untuk menentukan (memutuskan sesuatu), diartikan juga sebagai kemampuan menguasai gramatika suatu bahasa secara abstrak atau batiniah. Sedangkan dalam keputusan Menteri Pendidikan Nasional Nomor 045/U/2002 pasal 2 ayat (1) disebutkan bahwa yang dimaksud dengan kompetensi adalah seperangkat tindakan cerdas, penuh tanggungjawab yang dimiliki seseorang sebagai syarat untuk dianggap mampu oleh 
masyarakat dalam melaksanakan tugas-tugas di bidang pekerjaan tertentu. Sementara itu, Syaiful Sagala mendefinisikan kompetensi adalah perpaduan dari penguasaan, pengetahuan, keterampilan, nilai dan sikap yang direfleksikan dalam kebiasaan berpikir dan bertindak dalam melaksanakan tugas/pekerjaannya (2009: 29).

Kompetensi juga diartikan sebagai keterampilan, pengetahuan, sikap dasar serta nilai yang dicerminkan ke dalam kebiasaan berpikir dan bertindak yang sifatnya berkembang, dinamis, kontinyu (terusmenerus) serta dapat diraih setiap waktu. Kebiasaan berpikir serta bertindak dengan konstan, konsisten serta dilakukan terus menerus akan membuat seseorang menjadi kompeten (http://www.pengertianmenurutparaahli.net, posting tgl. 22. bln. Meret 2017 pukul. 08.35).

Menurut Gordon sebagaimana yang dikutip Mulyasa (2007: 38), bahwa ada enam aspek atau ranah yang terkandung dalam konsep kompetensi, yaitu; 1) Pengetahuan (knowledge), yaitu kesadaran dalam bidang kognitif, misalnya seorang guru mengetahui cara melakukan identifikasi kebutuhan belajar, dan bagaimana melakukan pembelajaran terhadap peserta didik sesuai dengan kebutuhannya, 2) Pemahaman (understanding), yaitu kedalaman kognitif dan afektif yang dimiliki oleh individu, misalnya seorang guru yang akan melaksanakan pembelajaran harus memiliki pemahaman yang baik tentang karakteristik dan kondisi peserta didik, 3) Kemampuan (skill), adalah sesuatu yang dimiliki oleh individu untuk melakukan tugas atau pekerjaan yang dibebankan kepadanya, misalnya kemampuan guru dalam memilih dan membuat alat peraga sederhana untuk memberikan kemudahan belajar kepada peserta didik, 4) Nilai (value), adalah suatu standar perilaku yang telah diyakini dan secara psikologis telah menyatu dalam diri seseorang, misalnya standar perilaku guru dalam pembelajaran (kejujuran, keterbukaan, demokratis, dan lain-lain), 5) Sikap (attitude), yaitu perasaan (senang, tak senang, suka, tidak suka) atau reaksi terhadap suatu rangsangan yang datang dari luar, reaksi terhadap krisis ekonomi, perasaan terhadap kenaikan gaji, dan lain-lain, 6) Minat (interest), adalah kecenderungan seseorang untuk melakukan suatu perbuatan, misalnya minat untuk melakukan sesuatu atau untuk mempelajari sesuatu (E.Mulyasa, 2007: 38). 
Dalam Undang-Undang Nomor 14 Tahun 2005 pasal 10 ayat (1) disebutkan bahwa terdapat empat kompetensi yang harus dimiliki oleh guru, yaitu; 1) Kompetensi Pedagogiik, 2) Kompetensi Keperibadian, Kompetensi Profesional, dan 4) Kompetensi Sosial.

Penjabaran kompetensi pedagogik yang dimaksud adalah kompetensi yang berkaitan dengan pengelolaan pembelajaran yaitu kemampuan guru dalam mengelola pembelajaran peserta didik. Untuk itu, kompetensi ini menggambarkan bagaimana kemampuan guru dalam mengajar. Kompetensi ini dapat dilihat dari kemampuan menyusun rencana pembelajaran, kemampuan melaksanakan proses belajar mengajar, dan kemampuan melakukan evaluasi. Maka, guru harus menguasai ketiga kemampuan tersebut dalam kompetensi pedagogik.

Dalam Peraturan Pemerintah Nomor 74 Tahun 2008 pasal 3 ayat (4) bahwa kompetensi pedagogik merupakan kemampuan Guru dalam pengelolaan pembelajaran peserta didik yang sekurang-kurangnya meliputi; 1) Pemahaman wawasan atau landasan kependidikan, 2) Pemahaman terhadap peserta didik, sedikitnya terdapat empat hal yang harus dipahami guru dari peserta didiknya, yaitu; (1) tingkat kecerdasan, (2) kreativitas, (3) kondisi fisik, dan (4) pertumbuhan dan perkembangan kognitif (E.Mulyasa, 2011: 95). Kemudian hal yang penting berkaitan dengan ini adalah pengembangan kurikulum dan silabus. Pembuatan keputusan dalam pembinaan kurikulum bukan saja menjadi tangung jawab para perencana kurikulum, akan tetapi juga menjadi tanggung jawab para guru disekolah. Guru harus mampu membuat aneka macam keputusan dalam pembinaan kurikulum. Pada dasarnya betapa pun baiknya suatu kurikulum, berhasil atau tidaknya akan sangat bergantung kepada tindakantindakan guru di sekolah dalam melaksanakan kurikulum itu. Dalam hubungan ini, banyak ahli telah menyarankan tentang cara sistematik. Adapun beberapa prinsip umum yang dijadikan dasar dalam pengembangan kurikulum antara lain; 1) prinsip relevansi, 2) prinsip fleksibilitas, 3) kontinuitas, 4) praktis, dan 5) efektivitas. (Oemar Hamalik, 2008: 20).

Menurut Sukmadinata (2010: 150), kurikulum pada dasarnya berintikan empat dasar utama yaitu: tujuan pendidikan, isi, pengalaman belajar dan penilaian. Interelasi antara keempat aspek tersebut serta antara 
aspek-aspek tersebut dengan kebijaksanaan pendidikan perlu selalu mendapat perhatian dalam pengembangan kurikulum. Guru yang baik antara lain harus mampu membina program belajar mengajar yang baik serta menilai dan melakukan pengayaan terhadap materi kurikulum yang telah digariskan. dikatakan bahwa guru yang baik adalah guru yang mampu menciptakan pengajaran yang baik. Pengajaran yang baik adalah pengajaran yang berhasil melalui proses pengajaran yang efektif, maka setiap guru harus mempu melaksanakan pengayaan terhadap materi kurikulum sesuai dengan masyarakat setempat dan kebutuhan belajar siswa dalam kelas bersangkutan (Oemar Hamalik, 2008: 23-24).

Guru berperan penting dalam proses pembelajaran terutama dalam membantu peserta didik untuk belajar, membangun kemandirian berpikir, membangkitkan rasa ingin tahu, dan menciptakan kondisi belajar yang nyaman. Kinerja dan kompetensi guru memikul tanggung jawab utama dalam tranformasi orientasi siswa. Guru senantiasa membantu siswa menyerap dan menyusuaikan diri dengan informasi baru melalui proses menggali, bernalar, bertanya, mencipta, dan mengembangkan caracara tertentu dalam memecahkan permasalahan kehidupan.

Kompetensi yang dimiliki oleh setiap guru akan menunjukkan kualitas guru dalam mengajar. Dengan kata lain, kompetensi tersebut akan terwujud dalam bentuk penguasaan pengetahuan dan profesional dalam menjalankan fungsi sebagai guru. Maka, guru yang berkompeten dan profesional adalah guru yang piawai dalam melaksanakan profesinya.

Berdasarkan uraian tersebut dapat difahami garis besarnya bahwa kompetensi pedagogik guru adalah kemampuan mengelola pembelajaran peserta didik yang meliputi pemahaman terhadap peserta didik, perancangan dan pelaksanaan pembelajaran, evaluasi pembelajaran, dan pengembangan peserta didik untuk mengaktualisasikan berbagai potensi yang dimilikinya.

\section{Metodologi}

Tempat penelitian ini dilaksanakan di SMP Negeri 3 Karawang, Jalan Tampomas No. 2 Desa Karang Pawitan, Kecamatan Karawang Barat, Kabupaten Karawang, Provinsi Jawa Barat. Adapun waktu penelitian ini telah dilaksanakan pada semester genap 
tahun pelajaran 2016-2017 kurang lebih selama 10 bulan terhitung mulai bulan Maret 2017 sampai dengan Desember 2017.

Jenis penelitian ini
menggunakan metode kuantitatif. Metode kuantitatif dinamakan metode tradisional, karena metode ini sudah cukup lama digunakan sehingga sudah mentradisi sebagai metode untuk penelitian. Metode ini disebut sebagai metode positivistik karena berlandaskan pada pada filsafat positivisme. Dalam penelitian kuantitatif yang penulis lakukan dilandasi pada suatu asumsi bahwa suatu gejala itu dapat diklasifikasikan, dan hubungan gejala bersifat kausal (sebab akibat), maka peneliti dapat melakukan penelitian dengan memfokuskan kepada beberapa variabel saja (Tukiran Tanureja, 2012: 127). Metode ini sebagai metode ilmiah/scientic karena telah memenuhi kaidah-kaidah ilmiah yaitu konkrit/empiris, obyektif, terukur, rasional, dan sistematis. Metode ini juga disebut discovery karena dengan metode ini dapat ditemukan dan dikembangkan berbagai iptek baru. Metode ini disebut metode kuantitatif karena data penelitian berupa angka-angka dan analisis menggunakan statistik (Sugiyono, 2009: 7).
Peneliti melakukan penelitian kepada sejumlah subjek dan objek penelitian, yaitu para guru mata pelajaran pendidikan agama Islam yang berjumlah lima orang, dengan perincian yaitu; guru PAI KIs $X$ satu orang, guru PAI Kls XI dua orang, dan guru PAI Kls XII dua orang. Mengingat jumlah populasi penelitian sedikit, penulis merujuk pendapat Arikunto, bahwa apabila subjeknya kurang dari 100, lebih baik diambil semua, sehingga penelitiannya merupakan penelitian populasi (Suharsimi Arikunto, 2006: 112). Teknik pengumpulan data menggunakan konsep Sugiyono, yaitu melalui teknik dokumentasi, observasi dan kuesioner (angket) dan gabungan ketiganya (Sugiyono, 2009: 137). Kuesioner sebelumnya diujicobakan dulu dan dikonsultasikan kepada ahli sebelum digunakan untuk diuji validitasnya dengan rumus Product Moment Pearson dan diuji realibilitasnya dengan rumus Alpha Cronbach. Analisis data menggunakan analisis statistik deskriptif. Uji validitas yang dilakukan dengan cara menggunakan pilihan fungsi rumus yang ada pada perangkat microsoft excel, hasil perhitungan menggunakan microsoft excel sama dengan hasil perhitungan secara manual dengan menggunakan rumus korelasi product 
moment, dengan rumus Karl Pearson (Suharsimi Arikunto, 2006: 170).

Dalam menganalisis data digunakan teknik skoring berdasarkan kuisioner yang disebarkan kepada responden berdasarkan skala model Likert yang berisi sejumlah pertanyaan yang menyatakan objek yang hendak diungkap. Penskoran atas kuesioner menggunakan skala model Likert.

Dalam penelitian ini, untuk mengetahui ada tidaknya pengaruh antara penggunaan sosial media wathshapp terhadap kedisiplinan peserta didik pada mata pelajaran agama Islam, maka pengolahan data penelitian ini menggunakan rumus analisis Korelasi Product Moment. Variabel yang diujikan adalah korelasi antar dua variabel yang terdiri dari dependent varibel yaitu varibel yang terikat atau variabel yang dipengaruhi dan independent variabel atau disebut juga variabel bebas. Karena penelitian ini membahas dua variabel yang diteliti untuk selanjutnya dialkukan tabulasi data, diolah dengan rumus statistik dan dilakukan analisis. Adapun teknik analisis data yang dilakukan melalui beberapa tahapan, yaitu dengan cara mencari angka korelasi dengan rumus dari Karl Pearson di bawah ini :

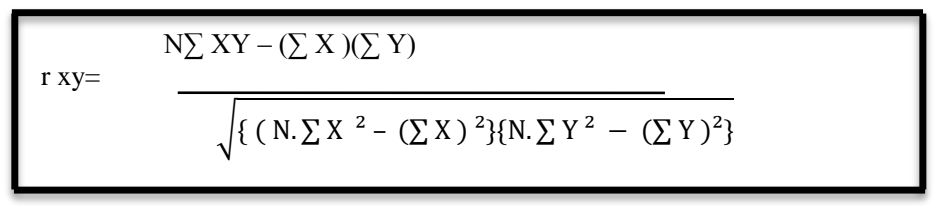

Keterangan :

Rxy = Angka Indek Korelasi "r" Product Moment

$\mathrm{N} \quad=$ Number of sample

$\sum x y=$ Jumlah hasil perkalian antara skor $X$ dan $Y$

$\Sigma X=$ Jumlah skor variabel $X$

$\sum Y=$ Jumlah skor variabel $Y$

Setelah data diolah dengan rumus di atas, maka dialakukan interprestasi data terhadap $r$ x y interprestasi sederhana dengan mencocokan hasil hitungan dengan angka indek pengaruh " $r$ " Pearson Product Moment.

Untuk mengetahui sejauhmana hubungan antara variabel bebas dan variabel terikat maka dilakukan uji signifikasi dengan rumus (Darwansyah, 2010: 98).

$$
t=r=\sqrt{\mathrm{n}-2}
$$




$$
\begin{aligned}
& \sqrt{1-r^{2}} \\
\mathrm{r}= & \text { Nilai koefisien korelasi } \\
\mathrm{n}= & \text { Jumlah sampel }
\end{aligned}
$$

Selanjutnya peneliti melakukan interpretasi data yaitu dengan angka indek korelasi yang dijadikan patokan untuk mengetahui besar kecilnya kekuatan pengaruh (kuat, lemah, atau tidak ada) diantara variabel yang diteliti. Dalam masalah ini ada dua macam cara dapat ditempuh, yaitu; 1) Interpretasi secara sederhana, dan 2) Interpretasi dengan menggunakan nilai "r" Pearson Product Moment.

Adapun yang dimaksud interpretasi secara sederhana yaitu melihat tingkat keeratan korelasi atau korelasi atau pengaruh antar variabel dapat dilhat dari angka koefisien korelasi yang disajikan dalam bentuk tabel interprestasi koefisien korelasi sebagai berikut:"

Tabel 1

Interpretasi Koefisien Korelasi/Pengaruh

\begin{tabular}{|c|l|}
\hline Interval Koefisiensi & \multicolumn{1}{|c|}{$\begin{array}{c}\text { Interpretasi } \\
\text { (Tingkat Pengaruh) }\end{array}$} \\
\hline $0,80-1,000$ & Sangat Kuat \\
$0,60-0,799$ & Kuat \\
$0,40-0,599$ & Cukup Kuat \\
$0,20-0,399$ & Rendah \\
$0,00-0,199$ & Sangat Rendah \\
\hline
\end{tabular}

Sedangkan yang dimaksud interpretasi dengan menggunakan nilai "r" Pearson Product Moment, yaitu dengan cara menguji kebenaran dan kepalsuan yang telah dumuskan dengan cara membandingkan nilai "r' yang telah diperoleh dari perhitungan, dengan nilai yang tercantum dalam nilai $r$ tabel (rt) Pearson Product Moment, dengan terlebih dahulu mencari derajat bebas (db) atau degree of freedom dengan menggunakan rumus yaitu :

$\mathrm{df}=\mathrm{N}-\mathrm{nr}$

df : Degree of freedom

$\mathrm{N}$ : Number of sample

$\mathrm{Nr}$ : Banyaknya variabel yang dikorelasikan

Dengan diperoleh nilai df maka dicari besarnya "r" yang tercantum tabel nilai "r" Pearson Product Moment, pada taraf signifiksai 5\%. Jika nilai $r$ hitung lebih besar dari $r$ tabel 
maka (Ha) hipotesa alternatif disetujui atau diterima, dan sebaliknya hipotesa nol (Ho) tidak disetujui atau ditolak.

\section{Hasil dan Pembahasan}

Data hasil penelitian ini adalah data yang diperoleh berdasarkan rekap data isian responden terhadap kuesioner yang disebar setelah dilakukan uji validitas dan reliabilitas. Sebelum dilakukan pengujian hipotesis, terlebih dahulu dilakukan uji persyaratan data dengan uji normalitas dan uji linieritas. Uji normalitas dilakukan untuk mengetahui data yang digunakan berasal dari populasi yang berdistribusi normal. Sedangkan uji linieritas dilakukan untuk memperoleh persamaan dan besaran nilai $F$, sehingga dapat diketahui bahwa $\mathrm{F}$ memiliki model regresi linier sederhana.

Berdasarkan rekap data hasil penelitian variabel Pengaruh Kepemimpinan Kepala Sekolah Terhadap Peningkatan Kompetensi Pedagogik Guru PAI di SMPN 3 Karawang" tahun pelajaran 2016/2017 diperoleh data sebagaimana pada tabel di bawah ini:

Tabel 2

Rekapitulasi Data Angket Variabel X (Kepemimpinan Kepala Sekolah)

\begin{tabular}{|c|c|c|c|c|c|c|c|c|c|c|}
\hline \multirow{2}{*}{$\begin{array}{c}\text { No } \\
\text { Soa } \\
\text { I }\end{array}$} & \multicolumn{9}{|c|}{ Kategori Jawaban } & \multicolumn{2}{c|}{\multirow{2}{*}{ Jumlah }} \\
\cline { 2 - 10 } & $\mathbf{F}$ & $\%$ & $\mathbf{F}$ & $\%$ & $\mathbf{F}$ & $\%$ & $\mathbf{F}$ & $\%$ & $\mathbf{F}$ & $\%$ \\
\hline 1 & 4 & 80 & 1 & 20 & 0 & 0 & 0 & 0 & 5 & 100 \\
\hline 2 & 4 & 80 & 1 & 20 & 0 & 0 & 0 & 0 & 5 & 100 \\
\hline 3 & 1 & 20 & 4 & 80 & 0 & 0 & 0 & 0 & 5 & 100 \\
\hline 4 & 4 & 80 & 1 & 20 & 0 & 0 & 0 & 0 & 5 & 100 \\
\hline 5 & 3 & 60 & 2 & 40 & 0 & 0 & 0 & 0 & 5 & 100 \\
\hline 6 & 2 & 40 & 3 & 60 & 0 & 0 & 0 & 0 & 5 & 100 \\
\hline 7 & 1 & 20 & 4 & 80 & 0 & 0 & 0 & 0 & 5 & 100 \\
\hline 8 & 2 & 40 & 3 & 60 & 0 & 0 & 0 & 0 & 5 & 100 \\
\hline 9 & 4 & 80 & 1 & 20 & 0 & 0 & 0 & 0 & 5 & 100 \\
\hline 10 & 2 & 40 & 3 & 60 & 0 & 0 & 0 & 0 & 5 & 100 \\
\hline 11 & 0 & 0 & 3 & 60 & 2 & 40 & 0 & 0 & 5 & 100 \\
\hline 12 & 3 & 60 & 2 & 40 & 0 & 0 & 0 & 0 & 5 & 100 \\
\hline 13 & 3 & 60 & 2 & 40 & 0 & 0 & 0 & 0 & 5 & 100 \\
\hline
\end{tabular}




\begin{tabular}{|c|c|c|c|c|c|c|c|c|c|c|}
\hline 14 & 0 & 0 & 3 & 60 & 2 & 40 & 0 & 0 & 5 & 100 \\
\hline 15 & 1 & 20 & 4 & 80 & 0 & 0 & 0 & 0 & 5 & 100 \\
\hline 16 & 2 & 40 & 3 & 60 & 0 & 0 & 0 & 0 & 5 & 100 \\
\hline 17 & 2 & 40 & 3 & 60 & 0 & 0 & 0 & 0 & 5 & 100 \\
\hline 18 & 1 & 20 & 4 & 80 & 0 & 0 & 0 & 0 & 5 & 100 \\
\hline 19 & 2 & 40 & 3 & 60 & 0 & 0 & 0 & 0 & 5 & 100 \\
\hline 20 & 1 & 20 & 4 & 80 & 0 & 0 & 0 & 0 & 5 & 100 \\
\hline Jml & $\mathbf{4 2}$ & $\mathbf{8 4 0}$ & $\mathbf{5 4}$ & $\begin{array}{c}\mathbf{1 0 8} \\
\mathbf{0}\end{array}$ & $\mathbf{0}$ & $\mathbf{8 0}$ & $\mathbf{0}$ & $\mathbf{0}$ & & \\
\hline $\begin{array}{c}\text { Rata- } \\
\text { rata }\end{array}$ & $\mathbf{2 , 1}$ & $\mathbf{4 2}$ & $\mathbf{2 , 7}$ & $\mathbf{5 4}$ & $\mathbf{0}$ & $\mathbf{4}$ & $\mathbf{0}$ & $\mathbf{0}$ & $\mathbf{5}$ & $\mathbf{1 0 0}$ \\
\hline
\end{tabular}

Kategori:

$0 \%-25 \%=$ kurang

$26 \%-50 \%=$ cukup baik

$51 \%-75 \%$ = baik

$76 \%-100 \%$ = sangat baik

Dari tabel di atas penulis dapat simpulkan bahwa rekapitulasi data variabel $X$ tentang kepemimpinan kepala sekolah SMP Negeri 3 Karawang yaitu "Baik" hal ini dapat dilihat dari hasil presentase yaitu: "A" dengan rata-rata presentase $42 \%$, "B" dengan rata-rata presentase $54 \%$, "C" dengan rata-rata presentase $4 \%$, " $D$ " dengan rata-rata presentase $0 \%$, dengan demikian jumlah jawaban terbanyak adalah jawaban "B" sejumlah 54\% artinya hasil presentase variabel $\mathrm{X}$ yaitu baik karena kepala sekolah telah dipandang oleh guru PAI di SMPN 3 Karawang sebagai pemimpin yang memiliki integritas dalam kepemimpinannya, baik dalam sisi kepribadian, idealisme, supervisi, motivasi maupun intelektualnya.

Selanjutnya di bawah ini penulis tampilkan rekapitulasi data variabel $Y$ tentang kompetensi pedagogik guru PAI.

\section{Tabel 3}

Rekapitulasi Data Angket Variabel Y (Peningkatan Kompetensi Pedagogik Guru PAI)

\begin{tabular}{|c|c|c|c|c|c|c|c|c|c|c|}
\hline \multirow{2}{*}{$\begin{array}{c}\text { No } \\
\text { Soal }\end{array}$} & \multicolumn{8}{|c|}{ Kategori Jawaban } & \multicolumn{2}{|c|}{ Jumlah } \\
\cline { 2 - 11 } & \multicolumn{2}{|c|}{$\mathbf{A}$} & \multicolumn{2}{|c|}{ B } & \multicolumn{2}{|c|}{ C } & \multicolumn{2}{|c|}{ D } & \multicolumn{2}{c|}{} \\
\cline { 2 - 11 } & $\mathbf{F}$ & $\%$ & $\mathbf{F}$ & $\%$ & $\mathbf{F}$ & $\%$ & $\mathbf{F}$ & $\%$ & $\mathbf{F}$ & $\%$ \\
\hline 1 & 4 & 80 & 1 & 20 & 0 & 0 & 0 & 0 & 5 & 100 \\
\hline 2 & 4 & 80 & 1 & 20 & 0 & 0 & 0 & 0 & 5 & 100 \\
\hline 3 & 2 & 40 & 3 & 60 & 0 & 0 & 0 & 0 & 5 & 100 \\
\hline 4 & 3 & 60 & 2 & 40 & 0 & 0 & 0 & 0 & 5 & 100 \\
\hline
\end{tabular}




\begin{tabular}{|c|c|c|c|c|c|c|c|c|c|c|}
\hline 5 & 3 & 60 & 2 & 40 & 0 & 0 & 0 & 0 & 5 & 100 \\
\hline 6 & 1 & 20 & 4 & 80 & 0 & 0 & 0 & 0 & 5 & 100 \\
\hline 7 & 2 & 40 & 2 & 40 & 1 & 20 & 0 & 0 & 5 & 100 \\
\hline 8 & 3 & 60 & 2 & 40 & 0 & 0 & 0 & 0 & 5 & 100 \\
\hline 9 & 3 & 80 & 2 & 20 & 0 & 0 & 0 & 0 & 5 & 100 \\
\hline 10 & 2 & 40 & 3 & 60 & 0 & 0 & 0 & 0 & 5 & 100 \\
\hline 11 & 1 & 20 & 2 & 40 & 2 & 40 & 0 & 0 & 5 & 100 \\
\hline 12 & 2 & 40 & 2 & 40 & 1 & 20 & 0 & 0 & 5 & 100 \\
\hline Jumlah & $\mathbf{3 0}$ & $\mathbf{6 2 0}$ & $\mathbf{3 6}$ & $\mathbf{5 0 0}$ & $\mathbf{4}$ & $\mathbf{8 0}$ & $\mathbf{0}$ & $\mathbf{0}$ & & \\
\hline $\begin{array}{c}\text { Rata- } \\
\text { rata }\end{array}$ & $\mathbf{2 , 5}$ & $\mathbf{5 1 , 7}$ & $\mathbf{3}$ & $\mathbf{4 1 , 7}$ & $\mathbf{0 , 3}$ & $\mathbf{6 , 7}$ & $\mathbf{0}$ & $\mathbf{0}$ & $\mathbf{5}$ & $\mathbf{1 0 0}$ \\
\hline
\end{tabular}

Dari tabel di atas penulis dapat simpulkan bahwa rekapitulasi data variabel $Y$ tentang Peningkatan Kompetensi Pedagogik Guru PAl di SMP Negeri 3 Karawang yaitu "Sangat Baik" hal ini dapat dilihat dari hasil presentase yaitu: " $A$ " dengan rata-rata presentase $51,7 \%$, "B" dengan ratarata presentase $41,7 \%$, " $\mathrm{C}$ " dengan rata-rata presentase $6,7 \%$, " $D$ " dengan rata-rata presentase $0 \%$, dengan demikian jumlah jawaban terbanyak adalah jawaban "A" sejumlah 51,7\% artinya hasil presentase variabel $Y$ yaitu baik karena dari hasil angket yang disebar pada Guru PAI telah menjawab bahwa ada keterkaitan antara kepemimpinan kepala sekolah dan peningkatan kompetensi pedagogik guru PAl di SMPN 3 Karawang. 


\section{Pengujian Hipotesis (Pengolahan Data)}

Tabel 4

Tabel Kerja Koefisien Korelasi antara Variabel Kepemimpinan Kepala Sekolah (X) dengan Variabel Peningkatan Kompetensi Pedagogik Guru PAI (Y)

\begin{tabular}{|c|c|c|c|c|c|}
\hline $\begin{array}{c}\text { Responde } \\
\mathbf{n}\end{array}$ & $X$ & $\mathbf{Y}$ & $X^{2}$ & $\mathbf{Y}^{2}$ & $\mathbf{X Y}$ \\
\hline R 1 & 65 & 48 & 4.225 & 2.304 & 3.120 \\
\hline R_2 & 75 & 43 & 5.625 & 1.849 & 3.225 \\
\hline R_3 & 68 & 40 & 4.624 & 1.600 & 2.720 \\
\hline R_4 & 66 & 39 & 4.356 & 1.521 & 2.574 \\
\hline R_5 & 65 & 35 & 4.225 & 1.225 & 2.275 \\
\hline$\Sigma=5$ & $\Sigma X=339$ & $\Sigma Y=205$ & $\begin{array}{c}\Sigma X^{2} \\
=23.055 \\
\end{array}$ & $\Sigma Y^{2}=8.499$ & $\boldsymbol{\Sigma X Y}=13.914$ \\
\hline
\end{tabular}

Dari tabel di atas diketahui bahwa:

$$
\begin{array}{ll}
\Sigma X=339 & \Sigma Y=205 \\
\Sigma X^{2}=23.055 & \Sigma Y^{2}=8.499 \\
\Sigma X Y=13.914 & N=5
\end{array}
$$

Dari hasil perhitungan di atas sudah secara otomatis angka dapat dihitung, baik dihitung rata-rata dan standar deviasi, akan tetapi berikut ini perhitungan secara manual untuk mencari rata-rata dan standar deviasi agar menjadi semakin baik.

a. Rata-rata

$$
\begin{array}{ll}
X=\frac{\sum X}{N} & Y=\frac{\Sigma Y}{N} \\
X=\frac{339}{5} & Y=\frac{205}{5} \\
X=67,8 & Y=41
\end{array}
$$

b. Standar Devisi

$$
\begin{aligned}
\mathrm{S}_{1} & =\frac{\sqrt{n \sum X_{1}^{2}-\left(\sum X\right) 2}}{\mathrm{n}-(\mathrm{n}-1)} & \mathrm{S}_{2}=\frac{\sqrt{n \sum Y_{1}^{2}-(\Sigma Y) 2}}{\mathrm{n}-(\mathrm{n}-1)} \\
& =\frac{\sqrt{5(23055)-(339)^{2}}}{5-(5-1)} & =\frac{\sqrt{5(8499)-(205)^{2}}}{5-(5-1)}
\end{aligned}
$$




$$
\begin{array}{lc}
=\frac{\sqrt{115275-114921}}{5(4)} & =\sqrt{76495-42025} \\
=\frac{\sqrt{354}}{20} & =\frac{\sqrt{34470}}{20} \\
=\sqrt{724180791} & =\sqrt{715734463} \\
=2.69106074 & =2.67532141
\end{array}
$$

c. Koefisien korelasi (rumus product moment)

$$
\begin{aligned}
& r_{x y}=\frac{N \sum X Y-\left(\sum X\right)\left(\sum Y\right)}{\sqrt{\left[N \sum X^{2}-\left(\sum X\right)^{2}\right]\left[N \sum Y^{2}-\left(\sum Y\right)^{2}\right]}} \\
& r_{x y}=\frac{5 X 13.914-(339) X(205)}{\sqrt{\left[5 X 23.055-(339)^{2}\right]\left[5 X 8.499-(205)^{2}\right]}} \\
& r_{x y}=\frac{69.570-69.495}{\sqrt{[115.275-114.921][42.495-42.025]}} \\
& r_{x y}=\frac{75}{\sqrt{[354][470]}} \\
& r_{x y}=\frac{75}{\sqrt{166.380}} \\
& r_{x y}=\frac{75}{407,897} \\
& r_{x y}=0,183
\end{aligned}
$$

memberikan interpretasi angka indeks

Setelah dilakukan perhitungan dengan rumus korelasi product moment, maka diketahui bahwa $r_{2}=$ 0,183 maka langkah berikutnya adalah korelasi product moment secara kasat (sederhana). Dalam memberikan interpretasi secara sederhana 
terhadap angka-angka korelasi " $Y$ " prodauct moment $\left(r_{x y}\right)$ pada semuanya dipergunakan pedoman angka-angka sebagai berikut:

Tabel 4.42

Koefisien korelasi product moment

\begin{tabular}{|c|l|}
\hline "Y" Product moment $\left(\mathbf{r}_{\mathbf{x y}}\right)$ & \multicolumn{1}{|c|}{ interpretasi } \\
\hline $0,00-0,20$ & $\begin{array}{l}\text { Antara variabel } X \text { dan } Y \text { memang } \\
\text { terdapat korelasi, akan tetapi } \\
\text { korelasi itu sangat lemah atau } \\
\text { sangat rendah sehingga korelasi } \\
\text { itu diabaikan (dianggap tidak ada } \\
\text { korelasi antara variabel } X \text { dan } Y) .\end{array}$ \\
\hline $0,20-0,40$ & $\begin{array}{l}\text { Antara variabel } X \text { dan } Y \text { terdapat } \\
\text { korelasi yang lemah atau rendah. }\end{array}$ \\
\hline $0,40-0,70$ & $\begin{array}{l}\text { Antara variabel } X \text { dan } Y \text { terdapat } \\
\text { korelasi sedang atau cukup. }\end{array}$ \\
\hline $0,70-0,90$ & $\begin{array}{l}\text { Antara variabel } X \text { dan } Y \text { terdapat } \\
\text { korelasi yang kuat atau tinggi. }\end{array}$ \\
\hline $0,90-1,00$ & $\begin{array}{l}\text { Antara variabel } X \text { dan } Y \text { terdapat } \\
\text { korelasi sangat kuat atau sangat } \\
\text { tinggi. }\end{array}$ \\
\hline
\end{tabular}

Maka langkah selanjutnya adalah membandingkan dengan tabel koefesien product momen yang ada pada tabel 4.42 dari hasil yang penulis dapatkan dapat dikatakan variabel $\mathrm{X}$ memiliki efek yang sangat lemah terhadap variabel $\mathrm{Y}$.
Sedangkan koefisien korelasi determinasi dapat dihitung sebagai berikut:

d. Koefisien determinasi

$$
\begin{aligned}
\mathrm{KD} & =r^{2} \times 100 \% \\
& =0,183^{2} \times 100 \% \\
& =0,033489100 \% \\
& =3,3489 \%
\end{aligned}
$$


Setelah dihitung koefisien

determinasi maka dapat diketahui bahwa perubahan $Y$ dipengaruhi oleh $X$ sebesar 3,3489 untuk mengetahui lebih lanjut signifikasi hubungan antara variabel $X$ dengan variabel $Y$, kemudian dilakukan dengan uji $i$ sebagai berikut:

$$
I=r \sqrt{n-r 2}
$$

$$
\begin{aligned}
& \overline{\sqrt{1-r} 2} \\
= & \frac{0,183 \sqrt{5-2}}{\sqrt{1-0,033}} \\
= & \frac{0,183 \times 1,732}{\sqrt{0,967}} \\
= & \frac{0,316956}{0,983} \\
= & 0,3224374364 \\
= & 0,322 \%
\end{aligned}
$$

\begin{tabular}{|c|c|c|c|c|}
\hline \multirow{3}{*}{$\begin{array}{c}\text { Korelasi } \\
\text { antara }\end{array}$} & \multirow{3}{*}{$\begin{array}{c}\text { Koefisien } \\
\text { korelasi }\end{array}$} & \multirow{3}{*}{$\begin{array}{c}\text { Koefisien } \\
\text { Determinasi }\end{array}$} & \multicolumn{2}{|c|}{$\mathrm{T}_{\text {tabel }}$} \\
\hline & & & \multicolumn{2}{|c|}{ Signifikasi } \\
\hline & & & $1 \%$ & $5 \%$ \\
\hline$X \operatorname{dan} Y$ & 0,183 & 3,3489 & $0,805 \%$ & $0,878 \%$ \\
\hline
\end{tabular}

Tabel 4.43

Korelasi X dan Y

Berdasarkan uji hipotesis pada tabel di atas, yang ditunjukkan dengan nilai korelasi $(r)=\mathbf{0 , 1 8 3}>r$ tabel $1 \%=0,805 \%$ dan $r$ tabel $5 \%=0,878 \%$, artinya bahwa ada pengaruh yang signifikan tentang pengaruh kepemimpinan kepala sekolah terhadap peningkatan kompetensi pedagogik guru PAI di SMPN 3 Karawang yang lemah.

\section{E. Penutup}

Berdasarkan hasil penelitian dan analisis uji hipotesis, maka dapat disimpulkan bahwa penelitian mengenai Pengaruh Kepemimpinan Kepala Sekolah Terhadap Peningkatan Kompetensi Pedagogik Guru PAI di SMP Negeri 3 Karawang sebagai berikut; berdasarkan rekapitulasi data variabel $X$ tentang kepemimpinan kepala sekolah di SMP Negeri 3 Karawang berkatagori "Baik". Hal ini dapat dilihat dari hasil presentase jawaban "B" sejumlah 54\% artinya hasil presentase variabel $X$ yaitu baik karena kepala sekolah telah dipersepsikan oleh guru PAI di SMPN 3 Karawang sebagai pemimpin yang 
memiliki integritas dalam kurikulum dan silabus, perancangan kepemimpinannya, baik dalam sisi pembelajaran, pelaksanaan kepribadian, idealisme, supervisi, pembelajaran yang mendidik dan motivasi maupun intelektualnya. dialogis, pemanfaatan teknologi Kualitas kompetensi kepemimpinan yang dimiliki kepala sekolah akan menjadi tolok ukur terhadap peningkatan kompetensi-kompetensi yang dimiliki guru, termasuk pada kompetensi pedagogik guru PAI di SMPN 3 Karawang.

Sedangkan rekapitulasi data variabel $Y$ tentang Peningkatan Kompetensi Pedagogik Guru PAI di SMP Negeri 3 Karawang berkatagori "Sangat Baik". Hal ini dapat dilihat dari hasil presentase jumlah jawaban terbanyak adalah jawaban "A", yaitu sebesar 51,7\%. Artinya hasil presentase variabel $Y$ yaitu sangat baik karena dari hasil angket yang disebar kepada Guru PAI telah memberi penilaian bahwa ada keterkaitan antara kepemimpinan kepala sekolah dan peningkatan kompetensi pedagogik guru PAI di SMPN 3 Karawang. Artinya Guru PAI telah memiliki kompetensi pedagogik yang sesuai dengan kebutuhan peserta didik dan lingkungan masyarakat baik dalam segi pemahaman wawasan atau landasan kependidikan, pemahaman terhadap peserta didik, pengembangan pembelajaran, evaluasi hasil belajar, pengembangan peserta didik untuk mengaktualisasikan berbagai potensi yang dimilikinya.

Berdasarkan uji hipotesis dan analisis, meskipun hasilnya dikatakan sangat lemah, namun terbukti ada pengaruh kepemimpinan kepala sekolah terhadap peningkatan kompetensi pedagogik guru PAI di SMPN 3 Karawang yang ditunjukkan dengan nilai korelasi $(r)=0,183>r$ tabel $1 \%=0,805 \%$ dan $r$ tabel $5 \%=$ $0,878 \%$, artinya bahwa ada pengaruh yang signifikan tentang pengaruh kepemimpinan kepala sekolah terhadap peningkatan kompetensi pedagogik guru PAI di SMPN 3 Karawang yang lemah.

\section{Daftar Pustaka}

Arikunto, S. (2006). Metodelogi Penelitian. Yogyakarta: Bina Aksara.

Darwansyah, dkk. ( 2010). Pengantar Statistik Pendidikan. Jakarta: GP Press.

Dhofier, Z. (2004). Sumbangan Visi Islam dalam Sistem Pendidikan Nasional dalam Menggagas Paradigma Baru Pendidikan Demokratisasi Otonomi Civil Society Globalisasi. Yogyakarta: Kanisius. 
Djiwandono. (2004). Globalisasi dan

Pendidikan Nilai, dalam

"Menggagas Paradigma Baru

Pendidikan Demokratisasi

Otonomi Civil Society

Globalisasi. Yogyakarta:

Kanisius.

Ginanjar, M. H. (2018).

KARAKTERISTIK

KEPEMIMPINAN PENDIDIKAN ISLAM BERBASIS

MASJID. Islamic Management: Jurnal Manajemen Pendidikan Islam, 1(01).

Hamalik, O. (2008). Pendidikan Guru Berdasarkan Pendekatan Kompetensi. Jakarta: Bumi Aksara.

Khalifah, M. U. (2012). Menjadi Guru Yang Dirindukan Bagaimana Menajadi Guru yang Memikat dan Profesional. Surakarta: Ziyad Books.

Koonttz, et.al. (1980). Management. Seventh edition, by McGrowHill, Inc.

M. As-Swaidan, T. U dan Faishal B. (2005). Melahirkan Pemimpin Masa Depan. Jakarta: Gema Insani.

M. Dalyono. (2009). Psikologi Pendidikan. Jakarta: Rineka Cipta, 2009.

Mulyasa, E. (2007). Standar Kompetensi dan Sertifikasi Guru. Bandung: PT Remaja Rosdakarya.

Musfah, J. (2015). Manajemen Pendidikan Teori, Kebijakan, dan Praktik. Jakarta: Prenada Media Group.

Peraturan Pemerintah Nomor 74 Tahun 2008.

Sagala, S. (2009) Kemampuan Professional Guru Dan Tenaga Kependidikan. Bandung: Alfabeta.

Sugiyono. (2009). Metode Penelitian Kuantitatif Kualitatif dan $R$ \& $D$. Bandung: Alfabeta.
Sulistiyorini. (2009). Manajemen Pendidikan Islam Konsep, Strategi dan Aplikasi. Yogyakarta: Teras.

Sukmadinata, N. S. (2010). Pengembangan Kurikulum Teori dan Praktek. Bandung: PT Remaja Rosdakarya.

Tafsir, A. (2011). Metodologi Pengajaran Agama Islam. Bandung: PT Remaja Rosdakarya.

Tanuredja, T. (2012). Penelitian Kuantitatif (Sebuah Pengantar. Bandung: Alfabeta.

Uha, I. N. (2014). Manajemen Perubahan. Bogor.

Undang-Undang Republik Indonesia No. 14 Th. (2005). Tentang Guru dan Dosen. Jakarta: Sinar Grafika.

Winardi. (2000). Kepemimpinan Dalam Manajemen. Jakarta: PT Rineka Cipta.

Wahjosumidjo. (2005). Kepemimpinan Kepala Sekolah Tinjauan Teoritik dan Permasalahannya. Jakarta: PT Raja Grafindo Persada.

(2013).

Kepemimpinan Kepala Sekolah, Jakarta: Rajawali Press.

Yukl, Gary A, Leadership in Organizations, Prentice-Hall, Inc., Englewood Cliffs, .N.J.07632, 1981.

Rujukan Internet:

http://www.pengertianmenurutparaahli. net. (2016). hari. Rabu. tgl. 22. bln. Meret 2017pukul. $08.35 \mathrm{Wib}$.

https://akhmadsudrajat.wordpress.com . hari. Senin. tgl. 20 Meret 2017. pukul $19.15 \mathrm{Wib}$.

https://kbbi.web.id, diposting tanggal 15 April 2017. 